BARER, G. R. (1951). J. gen. Microbiol. 5, 1-17.

\title{
The Action of Streptomycin on Bacterium lactis aerogenes
}

\author{
BY GWENDA R. BARER \\ Department of Physical Chemistry, University of Oxford
}

SUMMARY: The main action of streptomycin on Bacterium lactis aerogenes is bactericidal. In an 'untrained' population the number of cells able to survive in streptomycin diminishes with increasing concentration of the antibiotic. If the surviving cells are mutants, many mutant types must be assumed to explain the many degrees of resistance. Ability to survive does not necessarily imply ability to grow in streptomycin. Survivors sometimes have a long lag before growth occurs in liquid or solid media, which suggests that modification of cell protoplasm may be taking place. Colonies picked from high-concentration streptomycin plates often contain so many non-resistant cells that their origin from a single resistant mutant is unlikely. Training to grow in streptomycin may involve a mixed process of selection (by killing) and adaptation. There is close correspondence between the degree of resistance and the training concentration. Partial dependence on streptomycin is acquired. An attempt to 'train' a culture by a method designed to exclude selection was unsuccessful.

Morphological changes were found in untrained cultures grown in streptomycin.

Different samples from one culture frequently showed considerable variation in the number of apparently resistant cells present, depending at least partly on the dilution of the sample and the conditions of spacing on the plate. Resistance is a conditional property; in view of this it is dangerous to construct mutational theories on the evidence of variability between different cultures.

A study was made of the action of streptomycin on Bact. lactis aerogenes and of the way in which resistance was developed. It is generally believed that, for those species so far studied (Klein, 1947; Silver \& Kempe, 1947; Demerec, 1948), resistance develops when certain resistant cells in the population are selected in the presence of the antibiotic. The resistant cells are believed to arise by mutation before contact between the cells and the antibiotic takes place. The alternative hypothesis, that survival in streptomycin depends on the possession of a variable property, not necessarily due to mutation, and that survivors adapt themselves to growth in streptomycin by direct interaction between cell and antibiotic, has been inadequately explored. Linz (1948b), however, considered that his evidence supported the hypothesis of an induced change in the organism. Much evidence for the mutation theory rests on the fact that great variation exists in the resistance of different cultures of the same strain to streptomycin. This evidence may be interpreted in other ways, and the present study has sought to unravel the cause of this variability. An attempt was made to analyse the bacterial population with respect to resistance to streptomycin, before, during, and after single and repeated passages in presence of the antibiotic. It was hoped by this means to show either that every cell became adapted, or that very few cells became selected. The results emphasize the difficulty of the adaptation versus selection problem, and suggest that in some cases both processes may be at work. 


\section{METHODS}

The organism was Bact. lactis aerogenes N.C.T.C. No. 240. This was grown in a simple medium: $10 \mathrm{ml}$. glucose solution (50 g./l.), or $10 \mathrm{ml}$. glycerol solution (20 g./1.); $10 \mathrm{ml}$. $\mathrm{KH}_{2} \mathrm{PO}_{4}$ solution (9 g./l.), adjusted to $\mathrm{pH} 7 \cdot 1 ; 5 \mathrm{ml}$. $\left(\mathrm{NH}_{4}\right)_{2} \mathrm{SO}_{4}$ solution ( $5 \mathrm{~g} . / \mathrm{l}$.$) , or 5 \mathrm{ml}$. asparagine solution ( $5 \mathrm{~g} . / \mathrm{l}.) ; 1 \mathrm{ml} . \mathrm{MgSO}_{4}$ solution (1 g./l.). The solutions were boiled independently on three successive days and mixed before use (final $\mathrm{pH} \boldsymbol{\gamma \cdot \mathbf { 1 }}$, for glucose or glycerol). The organism had to be trained to grow in glycerol (Lodge \& Hinshelwood, 1944), but the use of this compound avoided the partial inhibition of streptomycin activity caused by glucose (Waksman, 1944). A thermostatically-controlled water-bath at $37^{\circ}$ (occasionally $40^{\circ}$ ) was used for incubating the tubes, which were aerated with a stream of sterile air. Streptomycin was added to media immediately before use. Streptomycin Ca complex (Merck) 1000 units/mg., or streptomycin sulphate (Lilley) 1000 units/mg., were generally used. For plate experiments $2 \%$ agar was added to the above media and the whole autoclaved. Streptomycin was added just before pouring plates (temperature less than $55^{\circ}$ ). For viable counts the plates were overdried before use by resting them inverted on their lids until they were able to absorb $0.02 \mathrm{ml}$. drops of medium within $20 \mathrm{~min}$. The method of viable counting was that of Miles \& Misra (1938). Tenfold dilutions of the culture in the stock medium were made with pipettes giving standard 0.02 ml. drops (Donald, 1915; Wilson, 1922). Two drops from each dilution were made on each of two plates, and allowed to dry at room temperature. Counts were made daily after incubation at $37^{\circ}$. The advantage of this method is that the count can be estimated from more than one dilution, a fact which proved of great importance. Total cell counts were made with a Hilger's 'Spekker' photoelectric absorptiometer calibrated against a haemocytometer $(0.02 \mathrm{~mm}$. depth). For growth curves lasting 3 or 4 days cultures were sometimes packed in ice overnight (Fildes \& Whitaker, 1948) with no effect on the curves.

\section{RESULTS}

\section{Resistance during first passage in streptomycin}

Growth curves. Liquid media containing streptomycin were inoculated (usually with $c .6 \times 10^{7}$ cells) from cultures which had just reached the end of the lag phase. Growth curves were constructed from viable counts of samples of the daughter cultures taken at intervals on control and on streptomycin plates (of same concentration as liquid medium). Fig. 1 shows that streptomycin had a bactericidal effect which was delayed in low concentrations; in very low concentrations much growth occurred before killing was evident (Fig. 1a). In other instances (Fig. 1b) growth and killing occurred simultaneously, since the total count rose while the viable count fell. It is noteworthy that the viable count on the streptomycin plate also fell initially. This may be due to streptomycin being less active under plate conditions than in liquid medium, so that the count on the streptomycin plate at the beginning of the experiment did not represent the number of cells completely resistant to 
that concentration in liquid medium. Another possible explanation consistent with other observations is that more cells grow on a streptomycin plate than are truly resistant when the inoculum is heavy (e.g. in early samples before killing has occurred to any great extent). The phenomenon might be due to non-
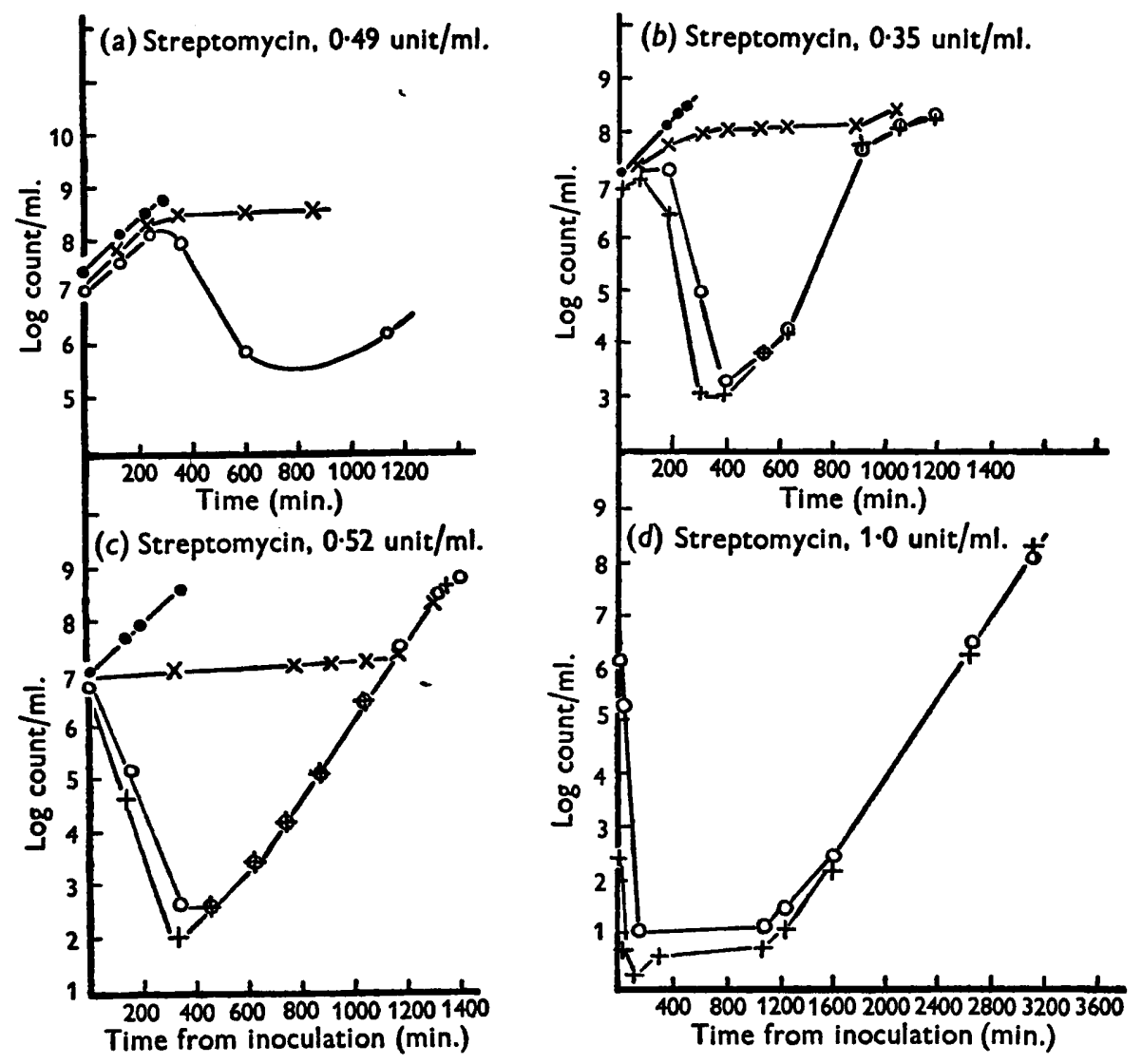

Fig. 1. Growth curves in presence of different concentrations of streptomycin. Glycerol ammonium sulphate medium. $37^{\circ}$. Spekker count from streptomy on plain agar plate; +-+ , viable count from streptomycin tube on plate containing same concentration streptomycin as tube.

resistant cells being able to utilize some substance produced by resistant cells and thus to grow. In later samples the non-resistant cells are dead and only completely resistant cells produce colonies. This explanation fits the fact that the apparent number of resistant cells in a sample diminishes with the dilution of the inoculum, and leads to the conclusion that this number can only be correctly assessed when estimated from a high dilution. When growth eventually occurs the counts on control and on streptomycin plates are usually the same even in high dilutions, suggesting that all cells are resistant. Occasionally after the period of rapid death, there is an interval during which the population is 
stationary (Fig. 1d), suggesting that the survivors require some time for adaptation before they can grow in streptomycin. In some cases a single resistant cell in the inoculum could have provided growth much sooner, but it is possible that the interval is due to the fact that the very small number of survivors have a long lag, not due to streptomycin, but similar to the lag pertaining in cultures with very small inocula. The 'small inoculum lag' did not occur with a medium containing asparagine as nitrogen source (Hinshelwood, 1946), and this observation was confirmed for inocula as small as 4 cells with the asparagine medium used in the present work. Nevertheless, long lags (in one case visible growth was not apparent until the eighth day) still occurred in streptomycin when asparagine was used as nitrogen source, so that it remains a possibility that the interval is occupied by adaptation.

\section{Resistance of untrained populations}

Population curves. When a culture is inoculated by the viable count technique onto a series of plates containing streptomycin, it is found that the percentage of cells able to survive and produce colonies diminishes with increasing streptomycin concentration. Fig. 2 shows the distribution of the ability to survive in the population. It cannot be proved that the cells which produced colonies on streptomycin plates were resistant initially, since they have grown in the presence of the antibiotic and may have become adapted during the process. However, various facts suggest that there is great variation in resistance in the original population, and that survival is not a matter of chance. On high concentration plates some colonies grow as soon as those on control plates, suggesting complete adaptation from the start. Many colonies appear late, however, and it is possible that adaptation is occurring during this interval. In a given concentration there is much greater variation in the time of appearance of colonies than there is on control plates. Sometimes a second crop appears after the first crop is established, suggesting that the latter provide some substance which the former requires for growth. The possibility that colonies which grow late develop from mutants occurring in minute colonies of non-resistant cells cannot be excluded, especially since such aborted colonies can sometimes be seen by microscopical examination. It is rendered unlikely, however, by the fact that the fully developed colonies may contain a large number of nonresistant cells (see Table 1). In low concentrations (e.g. Fig. 2, 0.5 unit/ml.) where all or nearly all cells survive, colonies appear later than on control plates. A rough picture of the change in population during growth was obtained when viable counts were made at intervals on a series of plates containing different concentrations of streptomycin during the growth of a culture in liquid medium containing streptomycin. It will be seen (Fig. $3 a$ ) that at first the count decreased on both control and streptomycin plates. When the total count had fallen nearly to the count of 'resistant' cells, growth began. The population curves plotted for different times (Fig. 3b), show that when killing ceased, it was mainly the growth of resistant cells that occurred; some non-resistant cells also grew, since the total count remained higher than that on streptomycin, even after growth had recommenced. 


\section{Resistance after one passage in streptomycin on solid medium}

Relating colonies from higher concentration plates on the same concentration of streptomycin and on control plates gave the results shown in Table 1. The proportion of resistants was usually greater than in the parent culture and

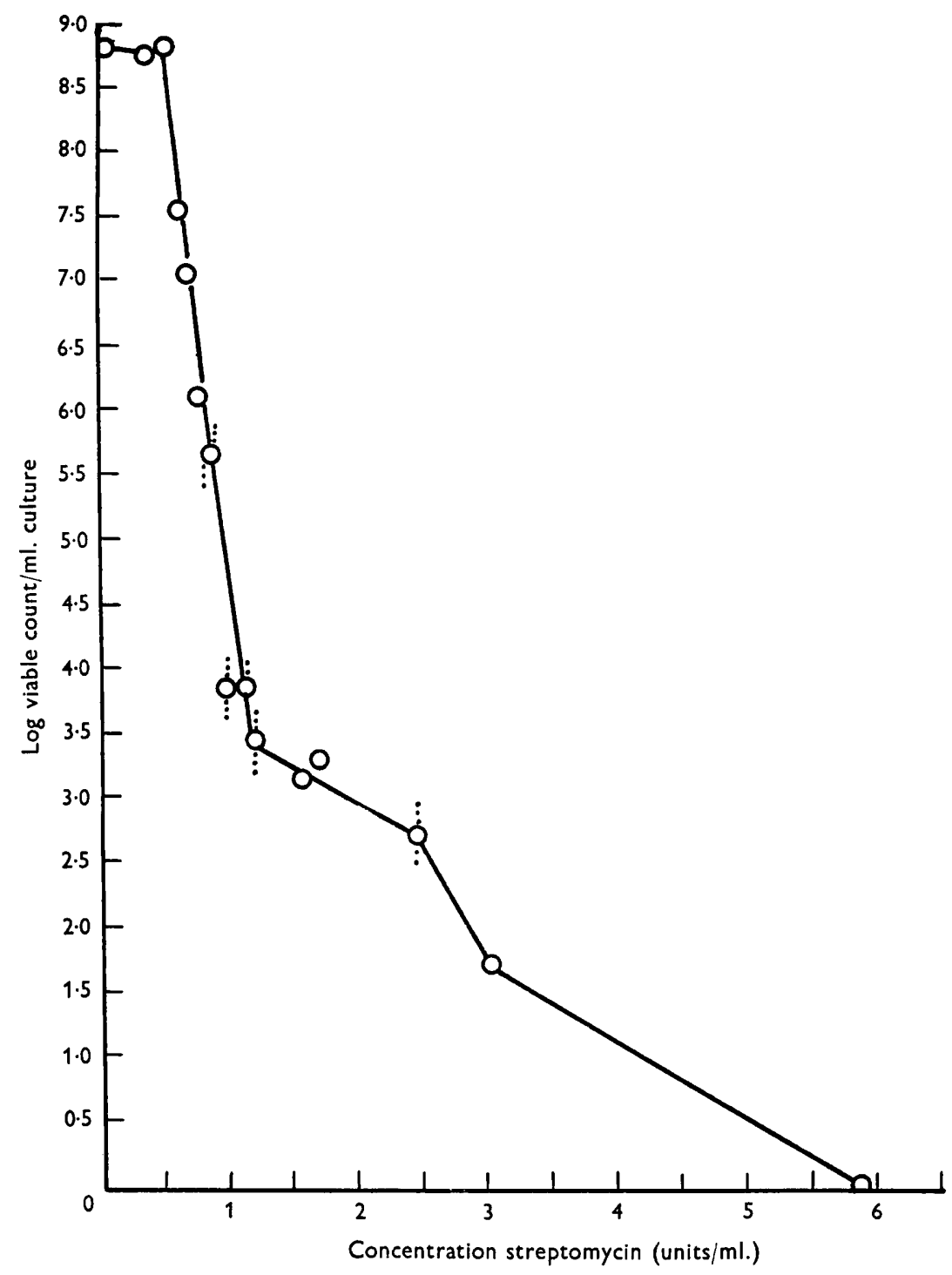

Fig. 2. Typical population curve of Bact. lactis aerogenes in streptomycin. Viable counts were made from a culture grown in normal medium at the end of the lag phase of growth on glycerol ammonium sulphate agar plates containing increasing concentrations of streptomycin. Counts were estimated from lowest dilution in which growth occurred. Where exact estimation was impossible (owing to variation between drops, or confluent growth in one dilution and no growth in the next) dotted lines are shown. Points represent final counts after 5 days' incubation. 
Table 1. The resistance of typical colonies from streptomycin plates

\begin{tabular}{|c|c|c|c|}
\hline \multirow[b]{2}{*}{$\begin{array}{c}\text { Colony } \\
\text { no. }\end{array}$} & \multirow{2}{*}{$\begin{array}{c}\text { Streptomycin } \\
\text { concentration } \\
\text { in plate } \\
\text { (units/ml.) }\end{array}$} & \multicolumn{2}{|c|}{ Counts on second passage } \\
\hline & & $\begin{array}{c}\text { Control } \\
\text { plate }\end{array}$ & $\begin{array}{c}\text { Streptomyc } \\
\text { plate }\end{array}$ \\
\hline & & \multicolumn{2}{|c|}{ (No. of cells $/ \mathrm{ml}$.) } \\
\hline $\mathbf{1}$ & $\mathbf{2 \cdot 5}$ & $90 \times 10^{6}$ & $70 \times 10^{6}$ \\
\hline 2 & $1 \cdot 3$ & $20 \times 10^{6}$ & $1 \times 10^{6}$ \\
\hline 3 & $\mathbf{2 \cdot 3}$ & $10 \times 10^{6}$ & $0.7 \times 10^{6}$ \\
\hline 5 & $\mathbf{3} \cdot \mathbf{3}$ & $300 \times 10^{6}$ & 25 \\
\hline 9 & $\mathbf{3 \cdot 5}$ & $40 \times 10^{8}$ & 25 \\
\hline 11 & $4 \cdot 4$ & $7 \times 10^{6}$ & c. 13 \\
\hline 12 & $4 \cdot 4$ & $20 \times 10^{6}$ & $1 \times 10^{3}$ \\
\hline 13 & $8 \cdot 0$ & $10 \times 10^{6}$ & $\mathbf{0}$ \\
\hline 14 & $16 \cdot 0$ & $2 \times 10^{6}$ & $\mathbf{0}$ \\
\hline
\end{tabular}

sometimes equalled the total count (Table 1, no. 1). In other instances the proportion of cells able to grow again on the streptomycin plate was so low (Table 1, nos. 5 and 13) that it seems improbable that colonies could have arisen from single resistant mutants. Such cells could only produce a population of the
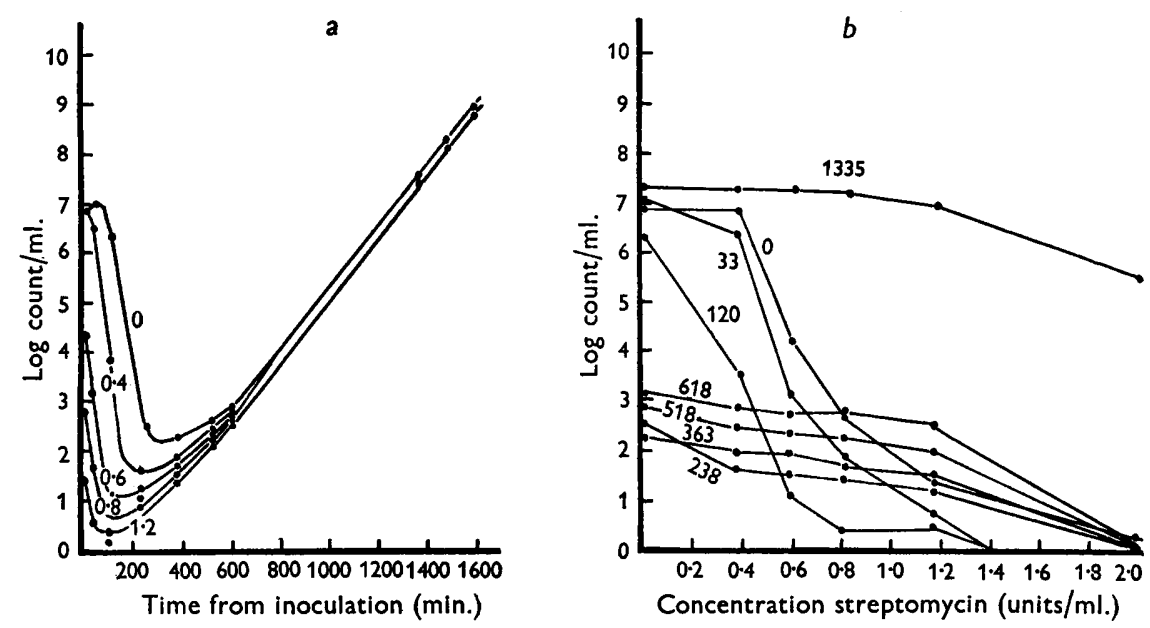

Fig. 3. (a) Growth curve of Bact. lactis aerogenes in $0.8 \mathrm{unit} / \mathrm{ml}$. streptomycin in glycerol ammonium sulphate medium at $37^{\circ}$. Viable counts made at intervals on control and streptomycin plates of varying concentration. Numbers on curves indicate units streptomycin/ml. (b) Population curves during growth of Bact. lactis aerogenes in $0.8 \mathrm{unit} / \mathrm{ml}$. streptomycin constructed from same data as $(a)$. Numbers on the curves indicate time in minutes from inoculation.

composition found, for example in Table 1 , no. 5 , if there were a very rapid back mutation rate combined with a high selective advantage for the nonresistant cells. Those colonies on high concentration plates showed many grossly abnormal cells not seen in controls or in trained cultures, which itself suggests that the colonies did not consist entirely of adapted cells. 


\section{Training to streptomycin on solid medium}

An attempt was made to devise a method which would show whether or not every cell in a sample could be made to grow in increasing concentrations of streptomycin, thus excluding the possibility that training was due to selection. Sample colonies from a streptomycin plate on which the full count grew (e.g. with streptomycin $\mathbf{0 . 5} \mathrm{unit} / \mathrm{ml}$.; Fig. 2) were emulsified, and subjected to viable counts on control plates and on a new series of streptomycin plates. It was hoped that on this second passage the highest concentration on which the full count grew (obtained from control plates) would be increased, and that from this concentration colonies could be picked off and the process repeated. In this way it might be possible to pick off colonies from increasing concentrations, showing that at each stage every cell had grown. This proved impossible for, as in the first transfer, there was either a lower count or delayed appearance of colonies on streptomycin plates compared with control plates (Table 2). Thus the majority of cells could not be trained to grow normally even in low concentrations.

Table 2. An attempt to train Bact. lactis aerogenes to growth in streptomycin on solid medium without selection

Scheme of training procedure. The inoculations made as under by the viable count technique:

Untrained liquid culture

$\left.\right|_{\text {Control }} ^{\text {Control plate }} \overbrace{\text { Control so on }}^{\begin{array}{l}\text { Streptomycin plates } \\ \text { Colony from highest concentration giving count } \\ \text { as high or nearly as high as control plate }\end{array}}$

Resistance of colonies finally tested:

\begin{tabular}{|c|c|c|c|c|}
\hline \multirow{3}{*}{$\begin{array}{c}\text { Colony } \\
\text { no. }\end{array}$} & \multirow{3}{*}{$\begin{array}{c}\text { Concentrations of } \\
\text { streptomycin through } \\
\text { which passed } \\
\text { (units } / \mathrm{ml} \text {.) }\end{array}$} & \multicolumn{2}{|c|}{$\begin{array}{l}\text { Viable counts } \\
\text { of colony emulsions }\end{array}$} & \\
\hline & & $\begin{array}{l}\text { Control } \\
\text { plate }\end{array}$ & $\begin{array}{c}\text { Streptomycin } \\
(0 \cdot 27 \text { units } / \mathrm{ml} .) \\
\text { plate }\end{array}$ & \\
\hline & & (Cel) & $.02 \mathrm{ml})$. & \\
\hline 1 & $0 \cdot 27,0 \cdot 27,0$ & $1 \times 10^{3}$ & 0 & \\
\hline 2 & $0.27,0.27,0.27,0.27$ & $4 \times 10^{5}$ & $2 \times 10^{5}$ & Lag* +++ \\
\hline 3 & $0 \cdot 27,0 \cdot 09,0 \cdot 27,0 \cdot 18$ & $2 \times 10^{3}$ & 10 & \\
\hline 4 & $0 \cdot 27,0 \cdot 09,0 \cdot 27,0 \cdot 27$ & $\mathbf{3} \times 10^{6}$ & $4 \times 10^{6}$ & Lag + \\
\hline 5 & $0 \cdot 27,0.09,0 \cdot 27,0.18$ & $2 \times 10^{6}$ & $1 \times 10^{6}$ & $\mathrm{Lag}+++$ \\
\hline 6 & $0 \cdot 27,0.27,0.27,0 \cdot 27$ & 20 & 10 & \\
\hline 9 & $0, \quad 0, \quad 0$, & $2 \times 10^{3}$ & $1 \times 10^{2}$ & Lag + \\
\hline 12 & $\begin{array}{llll}0, & 0, & 0, & 0\end{array}$ & $3 \times 10^{4}$ & $\mathbf{3} \times 10^{3}$ & $\operatorname{Lag}+++$ \\
\hline
\end{tabular}

* Lag = delayed appearance of colonies compared with those on control plates. 


\section{Variability in the results of tests}

The number of cells capable of giving rise to colonies on a given concentration depended largely on the dilution of the inoculum. Frequently confluent growth was obtained in one dilution, while in a tenfold dilution no colony was found. The opposite phenomenon also occurred (Table 3). Such a breakdown in dilutions did not occur with controls, and appeared to indicate that resistance was a conditional property. The growth of a few cells might provide materials

\section{Table 3. The effects of dilution on resistance to streptomycin on solid medium}

Typical viable counts

\begin{tabular}{|c|c|c|c|c|c|c|c|}
\hline \multirow{3}{*}{$\begin{array}{c}\text { Dilution } \\
\text { of culture } \\
\text { or emulsion } \\
\text { nil }\end{array}$} & \multicolumn{2}{|c|}{ Control plates } & \multicolumn{5}{|c|}{ Streptomycin plates (units/ml.) } \\
\hline & \multicolumn{7}{|c|}{$(\text { Cells } / 0.02 \mathrm{ml} .)^{3 \cdot 2}$} \\
\hline & $+t+$ & $+t+$ & $+t$ & ++ & ++ & - & - \\
\hline $1 / 10$ & +++ & $+t+$ & + & + & 2 & +++ & +++ \\
\hline $1 / 10^{2}$ & ++ & ++ & 48 & 52 & 65 & +++ & +++ \\
\hline $1 / 10^{3}$ & + & + & 30 & 60 & 23 & 0 & 0 \\
\hline $1 / 10^{4}$ & $\mathbf{5 5}$ & 64 & 11 & 17 & 11 & $\mathbf{0}$ & $\mathbf{0}$ \\
\hline $1 / 10^{5}$ & 7 & 8 & 2 & 0 & 0 & $\mathbf{0}$ & 0 \\
\hline Source of culture & \multicolumn{4}{|c|}{ 2.4 units/ml. plate } & $\begin{array}{c}\mathbf{3 \cdot 2} \\
\text { units } / \mathrm{ml} . \\
\text { plate }\end{array}$ & \multicolumn{2}{|c|}{$\begin{array}{c}\text { Untrained } \\
\text { liquid } \\
\text { culture }\end{array}$} \\
\hline
\end{tabular}

+++ , confluent growth; ++ , nearly confluent growth; + , separate colonies, too many to count.

enabling others to grow which would not have grown had they been in an isolated position. Linz (1948a) also showed that cells withstand varying concentrations of streptomycin according to their dilution. Much caution must be exercised if counts of resistant cells in a population are to be estimated from a single dilution. In the present work counts were estimated from the highest dilution in which growth occurred; when confluent growth occurred in one dilution and no growth in the next, the count was taken as 1 in the higher dilution. Luria \& Delbrück (1943) developed a statistical method for determining the origin of resistance to phage, and other workers (Demerec, 1945, 1948; Ryan, 1948; Scott, 1949) have applied it to other adaptation problems. These workers claim that non-Poisson variation in the counts of resistant cells in different cultures derived from identical non-resistant inocula is strong evidence for the origin of the resistant cells by mutation. Mutation would occur at different times in the different daughter cultures and give rise to clones of varying size. There would appear to be many factors which could cause such variation apart from mutation, the dilution effect being particularly important. However a diluted initial sample (used for inoculation), is sometimes compared, for numbers of resistant cells present, with an undiluted final sample. Experiments of this type have usually been performed on a series of cultures 18-24 hr. old; these would not all be at comparable stages of growth, 
which is another possible cause of variation. There would also be small differences in count. One culture serves as a control, and from it a large number of samples are taken to determine the sampling variability. These samples are all taken at one time, but if taken at slightly different times they might show a variation comparable to the non-Poisson variation of the whole series. In the present work, it was frequently found that there was great variation in the effect of streptomycin even on identical inocula from one culture; Table 4 illustrates this. Different drops on the same streptomycin plate from a calibrated Pasteur pipette may give very different counts (Table 4, no. 2), and if these drops are spread instead of being allowed to soak in, the count is usually much diminished (Table 4, nos. 3-5). This suggests that material carried over in

\section{Table 4. Variation in apparent resistance of samples}

(Viable counts were made on streptomycin plates from liquid media at end of log phase.)

\begin{tabular}{|c|c|c|c|}
\hline $\begin{array}{l}\text { Sample } \\
\text { no. }\end{array}$ & $\begin{array}{l}\text { Concentration } \\
\text { streptomycin } \\
\text { (units/ml.) }\end{array}$ & $\begin{array}{c}\text { Counts/individual drops }(0.02 \mathrm{ml} .) \\
\text { on plate (undiluted) }\end{array}$ & $\begin{array}{l}\text { Counts } / 5 \text { drops } \\
\text { spread across plate }\end{array}$ \\
\hline $\mathbf{1}$ & $\begin{array}{r}3.5 \text { plate } 1 \\
\text { plate } 2\end{array}$ & $\begin{array}{l}3,6,7,7,3,5 \\
0,6,1,0,2,5,6,11\end{array}$ & \\
\hline 2 & $\begin{array}{r}3.9 \text { plate } 1 \\
\text { plate } 2\end{array}$ & $\begin{array}{l}+++,+++,+++,+++,+++ \\
+++,+++,+++,+++, 50,50 \\
+++,++, 7,2,8,4,7 \\
\mathbf{1 3 , 4 , + , 5}\end{array}$ & \\
\hline 3 & $\begin{array}{l}4.4 \text { plate } 1 \\
\text { plate } 2\end{array}$ & $\begin{array}{l}0,3,2,2,1 \\
0,0,4,3,2\end{array}$ & $\begin{array}{l}\mathbf{0} \\
\mathbf{0}\end{array}$ \\
\hline 4 & $\begin{array}{r}3.5 \text { plate } 1 \\
\text { plate } 2\end{array}$ & $\begin{array}{l}10,7 \\
21,26\end{array}$ & $\begin{array}{r}7 \text { (10 drops) } \\
70 \text { (10 drops) }\end{array}$ \\
\hline 5 & $\begin{array}{r}3.5 \text { plate } 1 \\
\text { plate } 2 \\
\text { plate } 3 \\
\text { plate } 4\end{array}$ & $\begin{array}{l}26,25,27,33,43 \\
+++,+++,+++, 46,45 \\
30,+,+,+ \\
32,+,+,+,+\end{array}$ & $\begin{array}{l}17 \\
76 \\
34 \\
50\end{array}$ \\
\hline
\end{tabular}

the inoculum, or the proximity of other cells, may tip the balance in allowing a cell to grow in streptomycin. The counts show a reasonable distribution when the number of colonies is small but when the number is high they are extremely variable (Table 4, no. 5). In this particular medium the maximum population did not remain constant for long, so that no definite variation with age of cells, unaccompanied by a change in count, could be shown. Any trend which may have been present was swamped by differences between samples taken at any one time caused by the factors cited above. These arguments do not exclude that variability is due to mutations, but suggest that there may be other causes which should be taken into account.

In liquid media variability also occurs. Fig. 4, curve $a$, shows the lag/concentration curve for streptomycin. The time taken to reach a given count is taken as a measure of the effect of streptomycin and plotted against concentration. True lags cannot be used owing to the complex shape of the growth curves, so that a high count, which is only reached in the final growth phase (see Fig. 1), is chosen instead. The effect of a given concentration of streptomycin on a 
minimum lag culture was extremely variable even under carefully controlled conditions. This was true even when several lag/concentration curves were performed in parallel using similar inocula from the same parent, and appeared to be due mainly to slight shifts in the steep part of the curve. This had profound effects at certain concentrations (e.g. Fig. 5 at concentrations 0.015 and $0.02 \mathrm{unit} / \mathrm{ml}$. streptomycin). If the 'lag', as plotted here, represents the time taken for a few resistant cells to grow, the lag/concentration curve should be capable of being fitted to the population curve. It can be so fitted, but the $S$-shape of the curve renders this of doubtful value. In general, there is poor correspondence between the effect of streptomycin in liquid and solid media.

\section{Resistance after repeated passages in streptomycin}

Fig. 6 shows population curves made at intervals during the training of Bact. lactis aerogenes to grow in increasing concentrations of streptomycin. It was usually found possible to increase the concentration by increments of one third after each subculture. When the same process was carried out and at intervals the culture was tested in a series of concentrations in liquid media (in order to plot lag concentration curves) the picture seen in Fig. 4 was obtained. Both experiments showed that there was a close correlation between the average degree of resistance and the training concentration. This could occur on either theory. If there were some enzymic modification in direct response to the antibiotic, the degree of modification could depend on the concentration of streptomycin. If a selection of mutants of varying degrees of resistance were involved, only those mutants able to withstand a given concentration of streptomycin would be selected. Mutants resistant to concentrations higher than the training concentration would not be selected in preference to mutants of resistance equal to the training concentration, but they would nevertheless be selected. Their detection would depend on their frequency. It is difficult to envisage the large number of mutant types closely corresponding to each training concentration which these results would necessitate.

In curve $F$, Fig. 6 , more cells grew on a plate containing streptomycin than on the control plate, but at higher concentrations the count decreased. At a further stage of training more cells grew on the highest concentration used than on control plates (Fig. 6, curve $G$ ). Curve $F$ suggests extremely close gearing of the cell's economy to the concentration of streptomycin, such as one would hardly expect from a mutant, which, for example, grew better on streptomycin because it used it as a growth factor. One cannot, of course, show that the actual cells which cannot survive on a control plate but can survive on a 'low' concentration are those which are killed on a higher concentration, though the figures suggest this. The resistant strain was not in the full sense dependent (as were those of Miller \& Bohnhoff, 1947, and of Paine \& Finland, 1948) on streptomycin. Confluent growth was obtained on control plates in low dilutions, but in dilutions where separate colonies would be expected, none appeared. This is what is found with untrained cultures on streptomycin plates. In liquid media growth was obtained, however, from small inocula of the highly trained strain, in the absence of streptomycin. 


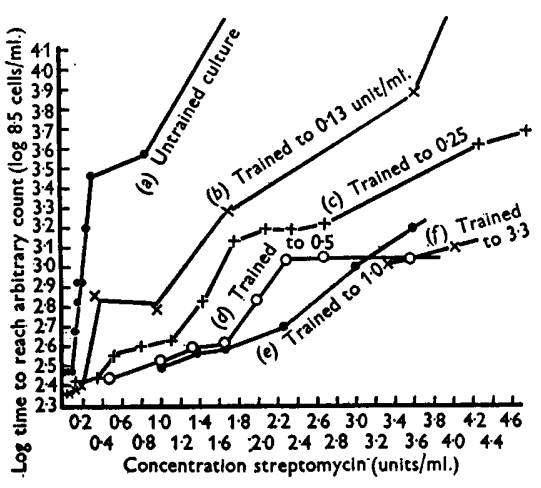

Fig. 4

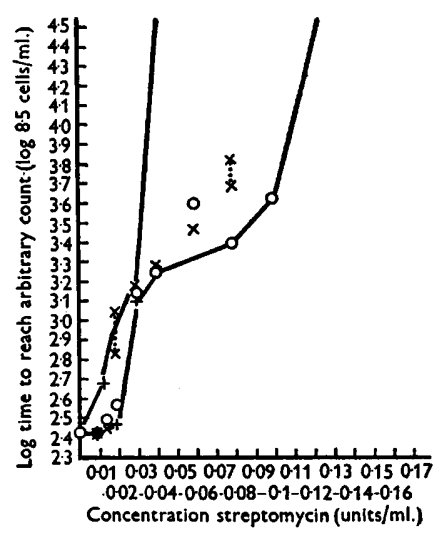

Fig. 5

Fig. 4. Typical lag/concentration curves of Bact. lactis aerogenes trained to various concentrations of streptomycin. Glucose ammonium sulphate medium (liquid) at $40^{\circ}$.

Fig. 5. Three lag/concentration curves of Bact. lactis aerogenes in streptomycin, to show variability. Identical inocula from same parent.

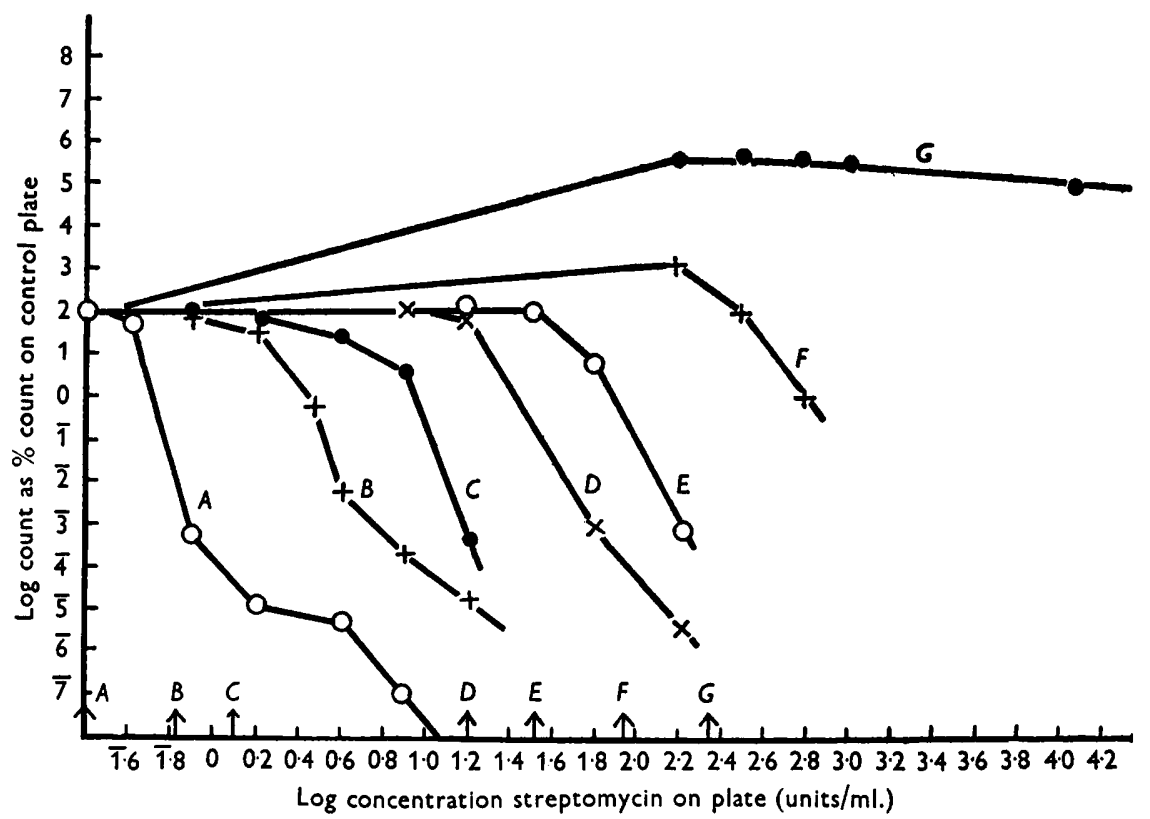

Fig. 6. Population curves during training of Bact. lactis aerogenes to streptomycin. Glycerol ammonium sulphate medium containing increasing concentrations of streptomycin. 37 ${ }^{\circ}$. $A, B, C$, etc., represent population curves constructed at intervals during training. Arrows show training concentration reached when population curves were constructed.

\section{DISCUSSION}

It seems clear that the adaptation of Bact. lactis aerogenes to growth in a given concentration of streptomycin involves the selection of those cells able to survive in that concentration. If the surviving cells owe their resistance to 
mutations which occur spontaneously before contact with streptomycin, the existence of many mutant types must be postulated to explain the many degrees of resistance. Some cells appear, from their rapid growth in streptomycin, to be completely adapted from the start, but most cells grow slowly or after a delay, suggesting the possibility that further adaptation is taking place. An alternative to the mutation hypothesis is that those cells survive which possess an extreme degree of some variable property (this might be a continuous variation depending on a polygenic system, rather than a mutation) and that direct modification of the protoplasm of survivors takes place in the presence of streptomycin. If such modification involved a change in the enzyme balance of the cells which afforded no disadvantage in normal media, it might be copied indefinitely (compare the permanence of antibody formation after removal of the antigenic stimulus). Such enzymic change need not violate the principle of the control of the cytoplasm by genes. The variation could occur within the limits imposed by the hereditary material, and might represent an alteration in the degree of manifestation of certain genes. Manifestation is known to vary with environmental conditions in Paramoecium (Sonneborn, 1948). However it must be emphasized that resistance to streptomycin has not been proved to be due wholly to mutation or to adaptation, and although certain of the facts do not readily conform to a mutation theory, none of the arguments are unequivocal. In particular it is difficult to explain the large numbers of nonresistant cells found in colonies on high concentration streptomycin plates; their growth is possibly to be attributed to over-crowding and 'assistance' effects. The fact that the lower the concentration of streptomycin the higher the count reached before killing occurs may suggest that streptomycin, in proportion to its concentration, impedes the availability of some essential substances, and that when these are exhausted death ensues.

The mutation versus adaptation problem in bacteria has become a battleground in biology. It may be worth while to discuss this with reference to the present work. Mutation is usually taken to mean that a new property has arisen spontaneously in the absence of the specific stimulus, but most of the properties studied require the presence of the stimulus for their demonstration. When 'mutants' are detected on test plates (e.g. containing drug, phage, or lacking an essential nutrient) the time of appearance of the colonies is of great importance, since if they are delayed as compared with colonies on control plates, adaptation may be occurring on the plate. This is not always recorded (e.g. Lewis, 1934). Jackson \& Hinshelwood (1950), working on the adaptation of Bact. lactis aerogenes to growth in D-arabinose, showed that similar counts could be obtained on glucose and on $\mathrm{D}$-arabinose plates, but that the colonies on the latter plates appeared only after a very long lag. The only reasonable interpretation here seems to be that adaptation took place. Even when colonies develop rapidly on test plates they may not be truly resistant since they are growing among large numbers of dead or inactive cells which may assist their growth (cf. Linz, 1948a). Also it is instructive to use a series of test plates containing concentrations of the antibiotic or essential metabolite, in order to construct population curves, as the so-called mutants may simply represent the tail of the 
distribution curve of the ability to synthesize an essential metabolite, or of the property which enables them to resist an antibiotic. This would explain why 'mutants' only appear in cultures which have reached a certain population size. In the present work it was demonstrated that the highest concentration of streptomycin permitting growth increased steadily with population size in a growing culture.

The statistical method developed by Luria \& Delbrück has afforded much of the evidence for the mutation theory, but it is open to the objection that all causes of variability other than mutation have not been ruled out. The shape of the lag/concentration curve for streptomycin shows that in a certain range of concentrations small changes in conditions beyond experimental control can cause enormous differences in the result. The resistance of a culture should be checked at several dilutions. In the present work counts of resistant cells were reproducible where the count was low, but extremely variable where it was high. In statistical experiments the diagnosis of non-Poisson variation has often depended on a few high counts. Also the theory of delayed phenotypic expression developed by Newcombe (1948) is based on the fact that two methods of calculating mutation rate on data obtained by the Luria \& Delbrück method yield different results. The one giving higher results was the one which included high counts in the calculation, which is just what would be expected if these counts are inflated by 'assistance' effects. Similar objections apply to experiments where large inocula are made into a series of tubes of drug-containing medium. If a small number of these tubes grow, it is no proof that the inocula contained resistant cells, since in high dilution growth might not have occurred, and adaptation might also have taken place in the tube.

In support of an adaptation theory it must be proved that every surviving cell adapts. Methods were devised in the present work in an attempt to satisfy these conditions, but they gave inconclusive results. Much support for this theory is based on its acceptability from the point of view of cell kinetics, the known existence of adaptive enzymes, and the intellectual difficulty of accepting the vast numbers of mutant types which would appear to be necessary to account for strains adapted to grow in innumerable antibiotics, drugs, phages, new sources of carbon and nitrogen, and even a whole spectrum of strains adapted to different concentrations of these agents. This close correspondence of the degree of resistance with the training is particularly clear-cut for proflavine (Davies, Hinshelwood \& Pryce, 1944; Davies \& Hinshelwood, 1945 $a$, $b$; Pryce, Davies \& Hinshelwood, 1945) and has been shown in the present work. Other workers, on the other hand, have obtained strains resistant to concentrations higher than that in which they had been trained (Silver \& Kempe, 1947; Demerec, 1948; Linz, 1948b); although this cannot be completely explained, it seems possible that the discrepancies are due to the use of different methods. Where strains are tested for resistance by a tube method (and this also applies to the egg method used by Silver \& Kempe) the highest concentrations in which growth occurs is a measure, not of the average resistance of the population (as was measured in the present work) but of the extreme 'tail' of the distribution of resistance in the population, since growth could have occurred from one 
resistant cell. This would not be expected to bear any relation to the training concentration. Moreover, if the inocula were large, growth of non-resistant cells might have occurred. Linz used fairly small inocula which partially obviates this objection, but on other grounds he interprets his results as due to active adaptation. It is in fact a possibility that strains resistant to higher concentrations than the training concentrations could arise by active adaptation, if the adaptation conferred a selective advantage on the cells.

It is very difficult to design conclusive methods in this field, but that of making viable counts from a liquid culture on to both drug and control plates during a phase of constant population (such as occurs during bacteriostasis due to a drug, or during a lag in a new medium) can give information as to the change in resistance of the population. The number, time of appearance, and rate of growth of colonies on the two sets of plates should be compared. Fig. 7 (a) shows the results which might be expected on the two theories for a hypothetical example. It has been claimed that colonies appearing late on a test-plate arise from mutants occurring in microcolonies. In this case some colonies would grow at once followed by a later crop of fairly constant lag; in contrast adapting ceils would show a lag which became smaller in successive samples. Repeated population curves made during a phase of stationary population might give results as in Fig. $7(b)$. If adaptation of the whole population is occurring the full count will grow from the outset on the drug plates (Fig. $7 a 2, b 2$ ) because, although adaptation will be incomplete in the early samples it may become complete on the plate. The method of training a culture on solid media by small changes in drug concentration so that every cell could grow (as determined by simultaneous counts on control plates) would provide good evidence for adaptation of the whole population if it could be achieved. The value of the method of replating apparently resistant colonies on further drug plates to see if they are truly resistant has been discussed.

Many results can be explained on either the adaptation or the mutation theory because the tests are inconclusive. Possibly each theory is true at times, and in some cases both may operate. It is reasonable to believe in mutation as the cause of recovery of a synthetic power lost during exposure to $\mathbf{X}$-rays, but not as the cause of origin of a whole series of strains adapted to different concentrations of a drug which the bacterium could not possibly have met before. There is also the possibility that selection may operate not only on mutants but on cells bearing a property showing continuous variation in the population. This might be a more plausible explanation for the origin of many degrees of resistance to a drug, than that of successive mutation steps (Demerec, 1948). There may also be less distinction between the two theories than is apparent, the essential point being whether or not adaptation is related to a specific stimulus. Hinshelwood (1946) pointed out that an increase in enzyme content per cell is a selection of cell protoplasm as distinct from a selection of individuals, but the result on the total bacterial mass is similar. The compromise idea that mutations may be induced by the specific stimulus is only a special case of the adaptation theory - the adaptation of a specific part of the cell. Enzymic expansion might represent the manifestation of a gene which could not show 
(1) Selection of mutants, other cells survive

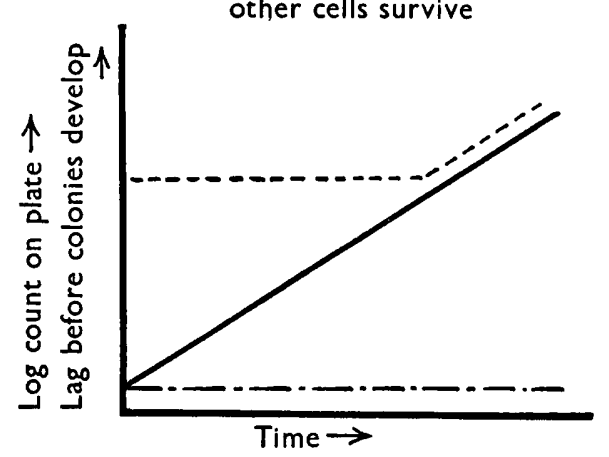

(3) Adaptation of survivors

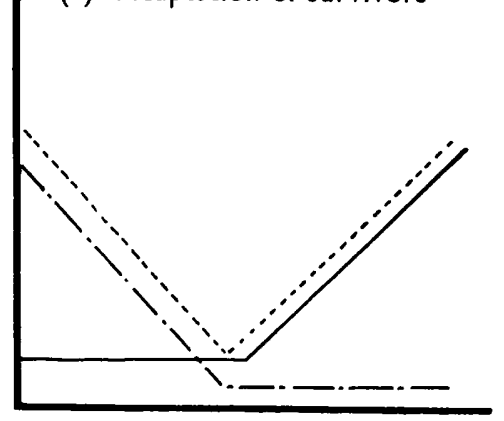

(1) Selection of mutants

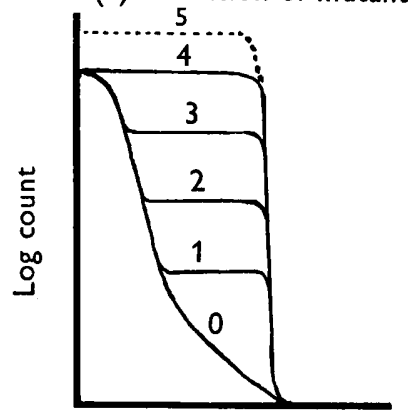

a

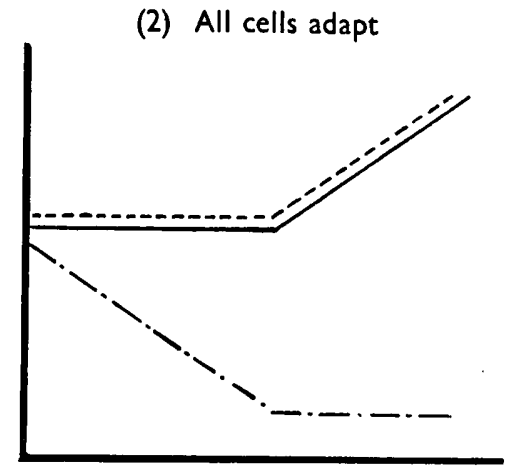

(4) Selection of mutants, other cells die

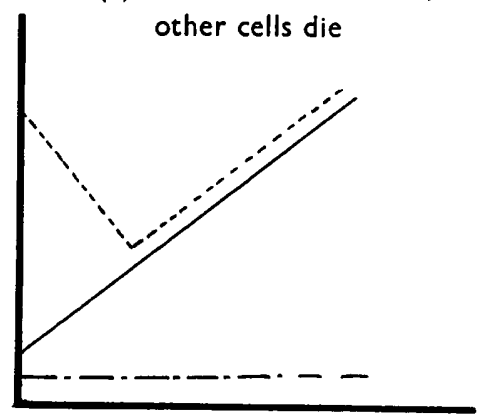

(2) All cells adapt

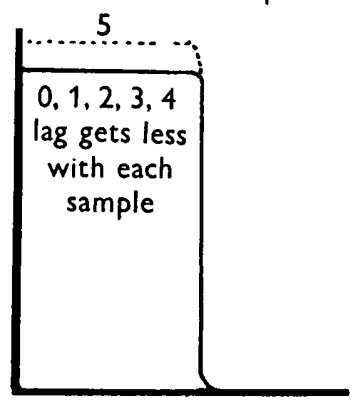

Concentration antibiotic

Fig. 7. (a) Hypothetical viable counts taken during lag phase of culture adapting to grow in new source of carbon (e.g. Bact. coli mutabile in liquid lactose medium). Counts made on glucose and lactose plates. (b) Hypothetical population curves constructed from samples taken at intervals from a culture of a bacterium adapting to an antibiotic in liquid medium during phase of constant population (bacteriostasis). Viable counts made on control and antibiotic plates of increasing concentration; in (b1) population not strictly constant as mutants are growing, but since these are few, total population would not appear to alter for some time. $(a) \ldots . .$. - count on glucose plate; - , count on lactose plate; - - - - , lag before colonies appear on lactose plate. (b) Numbers show time sequence of samples, .... - - shows population curve after growth is apparent. 
itself under wild conditions, and this would explain the correspondence between training concentration and resistance. It could provide a meeting ground between the two theories. The conception of the inheritance of acquired characters in bacteria need not be condemned as Lamarckian heresy since in bacteria every cell is a germ cell and subjected to variable conditions from which the germ cells of higher organisms are protected by the constancy of their 'milieu intérieur'. Mutation protagonists seem to attribute all bacterial variation to mutation whereas other processes, such as continuous variation and segregation (where sexual processes occur), have not been excluded. Much more fundamental knowledge of bacterial genetics is required before real advances in this subject can be expected.

Much gratitude is due to Sir Cyril Hinshelwood, F.R.S. (in whose department the work was carried out), for constant help and advice. I should also like to thank Dr E. P. Abraham and Dr J. H. Burnett who read the manuscript for their helpful discussion and criticism.

This work was carried out while the author was in receipt of a personal grant from the Medical Research Council.

\section{REFERENCES}

Davies, D. S., Hinshelwood, C. N. \& Pryce, J. M. (1944). Studies in the mechanism of bacterial adaptation. Trans. Faraday Soc. 40, 397.

Davies, D. S. \& Hinshelwood, C. N. (1945a). Adaptation of Bact. lactis aerogenes to varying concentrations of an antibacterial drug (proflavine). Trans. Faraday Soc. 41, 163.

Davies, D. S. \& Hinshelwood, C. N. (1945b). Adaptation of Bact. lactis aerogenes to high concentrations of proflavine. Trans. Faraday Soc. 41, 778.

Demerec, M. (1945). Production of Staphylococcus strains resistant to various concentrations of penicillin. Proc. nat. Acad. Sci., Wash., 31, 16.

Demerec, M. (1948). Origin of bacterial resistance to antibiotics. J. Bact. 56, 63.

Donald, R. (1915). A method of drop-measuring liquids and suspensions. Lancet, ii, 1243.

Findes, P. \& Whitaker, K. (1948). Training or mutation in bacteria. Brit. J. exp. Path. 29, 240.

Hinshelwood, C. N. (1946). The Chemical Kinetics of the Bacterial cell. Oxford: Clarendon Press.

JACKson, S. \& Hinshelwoon, C. N. (1950). An investigation of the nature of certain adaptive changes in bacteria. Proc. Roy. Soc. B, 136, 562.

KLEIN, M. (1947). A mechanism for the development of resistance to streptomycin and penicillin. J. Bact. 53, 463.

LEwIS, I. M. (1934). Bacterial variation with special reference to the behaviour of some mutabile strains of colon bacteria in synthetic media. J. Bact. 28, 619 .

Linz, R. (1948a). Relations entre la concentration bactériostatique de la streptomycine et la concentration des bactéries. C.R. Soc. Biol., Paris, 142, 1062.

Linz, R. (1948b). Effets des concentrations minimes de streptomycine sur les bactéries sensibles. C.R. Soc. Biol., Paris, 142, 1066.

Lodge, R. M. \& Hinshelwood, C. N. (1944). Adaptation of Bact. lactis aerogenes to certain changes of medium. Trans. Faraday Soc. 40, 571.

LuRIA, S. E. \& DELbrüCK, M. (1943). Mutations of bacteria from virus sensitivity to virus resistance. Genetics, 28, 491.

Mires, A. A. \& Misra, S. S. (1938). Estimation of bactericidal power of blood. J. Hyg., Camb., 38, 732. 
Miller, C. P. \& Bohnhoff, M. (1947). On the mechanism of development of streptomycin resistance. J. Bact. 54, 8.

Newcomвe, H. B. (1948). Delayed phenotypic expression of spontaneous mutants in E. coli. Genetics, 33, 447 .

Paine, T. F. \& Finland, M. (1948). Observations on bacteria sensitive to, resistant to, and dependent on streptomycin. J. Bact. 56, 207.

Pryce, J. M. G., Davies, D. S. \& Hinshelwood, C. N. (1945). Quantitative relation between the adaptations of Bact. lactis aerogenes to two antibacterial agents (methylene blue and proflavine). Trans. Faraday Soc. 41, 465.

Ryan, F. J. (1948). On the stability of nutritional mutants of bacteria. Proc. nat. Acad. Sci., Wash., 34, 425.

Scotr, G. W. (1949). Spontaneous mutation to streptomycin resistance in Escherischia coli. Brit. J. exp. Path. 30, 501.

Silver, H. K. \& Kempe, C. H. (1947). Resistance to streptomycin. A study of the mechanisms in its development. J. Immunol. 57, 263.

Sonnebonn, T. M. (1948). The determination of hereditary antigenic differences in genically identical Paramoecium cells. Proc. nat. Acad. Sci., Wash., 34, 413.

WAKSMAN, S. A. (1944). Isolation of antibiotic substances from soil micro-organisms with special reference to streptothricin and streptomycin. Proc. Mayo Clin. 19, 537.

Wilson, G. S. (1922). The proportion of viable bacteria in young cultures with special reference to the technique employed in counting. J. Bact. 7, 405.

(Received 5 August 1949) 